\title{
Fatty Acids Analysis of Photosynthetic Sulfur Bacteria by Gas Chromatography
}

\author{
María Teresa Núñez-Cardona \\ Universidad Autónoma Metropolitana-Xochimilco, \\ México
}

\section{Introduction}

The fatty acid profile of bacteria has been extensively studied for taxonomic classification purposes, as bacteria in general contain particular and rare fatty acids, compared with animal and plant tissues (Purcaro et al., 2010). Lipids and fatty acid composition are quite useful for characterization of different species and groups of photosynthetic bacteria. Fatty acids can be identified by gas chromatography using standard methods (Imhoff \& Caumette, 2004) because physical and chemical factors (e.g., illumination) influence bacterial fatty acid composition, culture conditions, and the culture media used for bacterial growth. Fatty acid analysis as a chemotaxonomic tool has been applied in heterotrophic bacteria, but its use in photosynthetic sulfur bacteria it is very limited. Actually, most studies on photosynthetic purple and green sulfur bacteria fatty acid composition have been done with relatively few genera and have often given information of the major fatty acids.

Purple and green sulfur photosynthetic bacteria are included in a physiological group called anoxygenic photosynthetic (or phototrophic) bacteria. They are anaerobes and do not produce oxygen from photosynthesis. They use reduced substrates, such as sulfide, hydrogen, ferrous iron and a great number of simple organic substrates, as photosynthetic donors (Imhoff, 2008). Photosynthesis in these microorganisms occurs thanks to bacteriochlorophylls, which could be type $a, b, c, d$, or $e$. Purple and green photosynthetic sulfur bacteria are Gram-negative and they are not phylogenetically related: purple sulfur bacteria are $\gamma$-Proteobacteria, and green sulfur bacteria are in a separated branch.

Photosynthetic Purple sulfur bacteria comprise the families Chromatiaceae and Ectothiorhodpiraceae. They are able to grow photoautotrophically and photoheterotrophically. Bacteriochlorophylls $a$ or $b$ and carotenes of the spirilloxhantin, rhodopinal, spheroidene and okenone series could be present as major pigments; these are located in membranes. According to Imhoff (2008), both families could be distinguished by chemotaxonomic properties through fatty acid composition.

Chlorobiaceae is a unique family of anoxygenic green photosynthetic sulfur bacteria. They are phototrophic and obligate anaerobes, and contain bacteriochlorophyll $c, d$, or $e$ in lightharvesting complexes located in the chlorosomes; their carotenoids could be clorobactene and isorenieratene. This family comprises the genera Chlorobium, Chlorobaculum, Prosthecochloris and Chloroherpeton (Imhoff \& Thiel, 2010). 
Information on fatty acid composition of purple and green photosynthetic sulfur bacteria is scarce, and this chapter shows new data on these important cellular components. Additionally, it includes general information about fatty acid nomenclature, the distribution of fatty acids in prokaryotic cells, and published information on fatty acids of photosynthetic purple and green sulfur bacteria; it also describes a standardized gas chromatography technique for fatty acid analysis of these photosynthetic bacteria using collection and wild strains, the last of which were isolated from Tampamachoco, a coastal lagoon localized in Veracruz, México.

\section{Fatty acids}

\subsection{Fatty acids nomenclature}

Fatty acids are the organic compounds most widely distributed in living organisms and are included within substances called lipids. They are rarely found free in nature; generally they are bound to a large variety of molecules, of which glycerol is the most common (Ratledge \& Wilkinson, 1988). Fatty acids that are ester-linked to glycerol are typical constituents of all Bacteria (Tindall et al., 2010). Lipids represent the most complex biological molecules and are crucial for cellular functions; the chemical and physical properties of these compounds determine a variety of roles in biological processes. According with Guschina \& Harwood (2008) lipids can be divided into two main groups: nonpolar lipids (acyl glycerols, sterols, free fatty acids, hydrocarbons, alcohols, wax, and steryl esters) and polar lipids (phosphoglycerides, glycosyglycerides, and sphingolipids).

Chemically, fatty acids are linear chain monocarboxylated compounds, and their general formula is $\mathrm{R}-\mathrm{COOH}$, in which group $\mathrm{R}$ is an unbranched linear chain containing between 8 and 26 carbon atoms (in bacteria). $\mathrm{R}$ groups are, therefore, characterized by the size of the chain, degree of unsaturation, the geometry of the double bond position, and by the presence of other substituents. They can be described as saturated or unsaturated (monounsaturated and polyunsaturated) depending on whether group $\mathrm{R}$ contains a double bond or not.

The nomenclature of these acids follows the $X: Y$ pattern, where $X$ is the total number of carbon atoms (not the total carbon atoms of the main chain), $Y$ is the number of double bonds [e.g., they can be di-enoic (two double bonds), tri-enoic (three double bonds) and so on]. Usually they are differentiated into monounsaturated fatty acids (one double bond) or polyunsaturated (two or more double bonds). To locate the double bonds, the $w Z c$ or $t$ method is followed in which $\mathrm{Z}$ indicates the number of carbon atoms in the aliphatic tail of the molecule, and $c$ and $t$ represent the cis and trans geometry, respectively. Branching is indicated by the $b r$ prefix. When the methyl group is on the penultimate carbon atom (distal from the carboxyl group) it is denoted as an iso fatty acid (sometimes as $w-1)$. Localization of hydroxyl $(\mathrm{OH})$, cyclopropane $(\mathrm{Cy}, \mathrm{Cyc}$ or cyclo) or methyl (me) groups, usually precede the X:Y formula (Ratledge \& Wikinson, 1988; Haack et al., 1994).

\subsection{Fatty acids in prokaryotic cells}

Among living organisms, microorganisms are probably the ones with the largest diversity regarding their fatty acid composition. They present from the simplest to the polyunsaturated, as in many filamentous cyanobacteria, mycobacteria, and some eukaryotic microorganisms. 
Microbial fatty acids can be completely saturated or contain several double bonds, although the presence of one or two double bonds is the most common. The site of these double bonds indicates their biosynthesis pathway. According to Scheuerbrandt \& Bloch (1962), the aerobic route for the synthesis of unsaturated acids is the same for all living organisms, but the anaerobic pathway is for bacteria. These authors suggested that adopting the oxidative pathway to synthesize unsaturated fatty acids throughout evolution allowed living organisms to abandon the anaerobic route, which is the most "primitive" and yet, perhaps more complex

The linear-chain fatty acids of bacteria are usually of the same class as those found in eukaryotic organisms, being part of membrane lipids with lengths that vary between 8 and 26 carbon atoms depending on the bacterial species. Bacterial monounsaturated fatty acids are primarily of type $\omega 7$ (unsaturation is located on carbon 7 from the methyl terminal), although type $\omega 9$, which is characteristic of higher organisms, can also be found.

In polyunsaturated fatty acids, the double bond is formed by dehydrogenation of one carbon-carbon bond, and is generally located in the center of the molecule ( $\omega 7$ or $\omega 9)$. Both the length of the fatty acid chain and the incorporation of double bonds (Abbas \& Card, 1980) participate in membrane fluidity. Hence the synthesis of longer-chain fatty acids causes the membrane to remain constant (Melchior, 1982 cited in Jantzen \& Bryan, 1985). Polyunsaturated fatty acids are common in mycobacteria containing phenolic acids of 36-38 carbons. They have also been observed in marine bacteria, such as Shewanella gelidimarina, Sh. hanedai, Sh. putrefaciens, Colwellia psychrerythraea, Flexibacter polymorphus (Russell \& Fukunaga, 1990), and in isolates of the Antarctic, in which these chemical compounds have chains of 18 to 20 carbon atoms (Nichols et al., 1997).

Dienoic fatty acids and others with a larger number of double bonds are more frequently found in eukaryotic organisms, but they have also been detected in some heterotrophic bacteria and cyanobacteria. The latter produce linoleic acid, which has also been found by Rabinowitch et al. (1993) in Escherichia coli, grown in both aerobic and anaerobic conditions.

The C18:2 (octadecadienoic) polyunsaturated fatty acid is produced by Aerobacter aerogenes and Pseudomonas sp., in which it contributes $18.2 \%$ and $24 \%$, respectively, to the total of their fatty acids, and in Serratia marcescens, contributing only $2.6-5.8 \%$ of the total extracted (Cho \& Salton, 1966). Although the $\gamma$-linolenic fatty acid, or C18:3 $(6,9,12)$, is a rare fatty acid outside the animal kingdom, it is commonly found in the oils of some seeds. Initially it was described in mycelial lipids of Phycomyces blakesleeanus (Lechevalier \& Lechevalier, 1988), and together with $\alpha$-linolenic, or C18:3 $(9,12,15)$, is part of the characteristic fatty acids of some cyanobacteria. The eicosapentaenoic acid (C20:5 $\omega 3)$ is produced by several strains of Shewanella in percentages from 2 to $40 \%$ of the total fatty acids (Yazawa, 1996; Brown et al., 1997; Nichols et al., 1997).

Yano et al. (1994) found docosahexaenoic acid (C22:6 13 or DHA) in a strain pertaining to the Vibrio genus and in the bacterial strain SCRC-21406 isolated from the gut of the deep-sea fish Glossanodon semifasciatus. Watanabe et al. (1997) reported the presence of this fatty acid in a proportion of 23\%, and extremely small amounts (less than $3 \%$ ) of other polyunsaturated fatty acids bound to their main phospholipids.

The polar lipids of several Spirulina strains contain $\gamma$-linolenic acid, particularly concentrated in their galactolipids (Durand-Chastel, 1997). Some Synecococcus strains also 
contain linoleic acid (18:2), a characteristic they share with other cyanobacteria like Gleocapsa, Chloroglea, and Microcystis (Kenyon, 1972).

Bacterial membranes of fatty acids consist of hydrophobic parts of glycerolipids and of lipid A. The hydrophobic parts exist in both Gram-positive and Gram-negative bacteria, whereas lipid $\mathrm{A}$ is only present in Gram-negative bacteria. This lipid usually contains several 3-OH fatty acid chains that can be used as a marker for detecting Gram-negative bacteria (Li et al., 2010).

Hydroxy fatty acids that carry an $\mathrm{OH}$ group, either in position two or three (2-OH-fatty acid or 3-OH-fatty acid), despite the fact that they are found in animal cells as D isomers, are frequently found in Gram-negative bacteria. They are generally a component of lipid A in their lipopolysaccharide, and, in some cases, they are also part of amino acids bound to lipids (Lechevalier \& Moss, 1977). The presence of lipopolysaccharide in Gram-negative bacteria gives rise to the presence of hydroxy fatty acids; thus the presence of 10:0 $3 \mathrm{OH}, 12: 0$ $3 \mathrm{OH}$, and/or 14:0 $3 \mathrm{OH}$ fatty acids indicates that the organism is Gram-negative bacteria. Conversely, the absence of the lipopolysaccharide and hydroxy fatty acids indicates that the organism is Gram-positive (Kunistky et al., 2006).

Cyclopropane fatty acids are formed by the addition of a methyl group from Sadenosylmethionine in the double bond of a pre-existing fatty acid (Cronan et al., 1979; Grogan \& Cronan Jr., 1997). In general, these fatty acids are part of the phospholipids of many bacterial species, and they have been related to the aging process of cells because they are produced in the stationary stage during their culture (Grogan \& Cronan Jr., 1997). Because of their instability, Jantzen \& Bryan (1985) recommend that, for their quantification, it is convenient to consider that their monounsaturated precursors are $\mathrm{C} 16: 1$ for $C y c 17: 0$, and C18:1 for Cyc19:0.

Fatty acids with alkyl branched chains are found in several bacterial groups. Methyl branches can be located in the last position (iso) or in the next-to-last (anti-iso), and, like unsaturated fatty acids their function is to regulate membrane fluidity (Jantzen \& Bryan, 1985).

In Gram-negative bacteria, the most frequent saturated fatty acids are C16:0, C18:0, and C14:0; the most important unsaturated fatty acids are C16:1 cis or trans 9 and the C18:1 cis or trans 11, hydroxyl acids, which are part of their lipopolysaccharides (Janse, 1997). Grampositive bacteria are characterized by the presence of important amounts of branched fatty acids; Coryneforms and Actynomicetes contain tubeculostearic and mycolic acids, respectively, and are exclusive to both genera (Ratledge \& Wilkinson, 1988).

It is important to mention that although branched fatty acids are characteristic of Grampositive bacteria, some Gram-negative can present them, such as Cytophaga, Flavobacterium, and Desulfobacter. It has been observed that they can make up almost $99 \%$ of the total fatty acid content in Flavobacterium thermophilum.

\subsection{Fatty acid distribution in purple and green photosynthetic sulfur bacteria}

\subsubsection{Fatty acids in Chromatiaceae family}

Anoxygenic photosynthetic bacteria as a group are unique among microorganisms because they do not exhibit the trans-3-hexadecenoic acid characteristic of the phosphatidylglycerol of photosynthetic eukaryotic organisms. The first studies on fatty acid composition of 
Chromatiaceae were performed by Newton \& Newton (1957) on Chromatium vinosum (strain D), and subsequently also analyzed by Haverkate et al. (1965) and Imhoff (1988). Thiocapsa roseopersicina (Thiocapsa floridana) was initially analyzed by Tacks \& Holt (1971); they recorded the presence of $\mathrm{C} 12: 0, \mathrm{C} 13: 0, \mathrm{C} 14: 0, \mathrm{C} 16: 1, \mathrm{C} 16: 0$ and $\mathrm{C} 18: 1$ in intact cells and membranes. Of these fatty acids, the last three supplied 20,28 , and $45 \%$, respectively.

Later studies, performed in Chromatium purpuratum 5500 (Imhoff \& Thiemann 1991), Thiocapsa roseopersicina strains 9314 and 6311, by Tacks \& Holt (1971) and Imhoff (1988), respectively; Thiocapsa sp. by Fredrickson (1986), Chromatium minus 1211, Chromatium warmigii 6512, and Thiocystis gelatinosa 2611 (Imhoff unpublished data, cited in Imhoff \& Bias-Imhoff, 1995), indicated that the major fatty acids found in these strains were C16:0 (19.7-30.3\%), C16:1 (25.4-36.5\%), C18:1 (32.3-43.8\%), small amounts of C14:0 (traces-1.3\%) and $\mathrm{C} 18: 0(0.8-2.0 \%)$.

Glycerophospholipid analyses in Thiocapsa sp. 5811, Amoebobacter roseus DSM235, Chromatium gracile DSM203, Chromatium vinosum (ATCC 17899), (DSM215), and in Thiocapsa sp. BF6400 and Chr. gracile BF7200, revealed the presence of at least 19 different fatty acids in the members of the Chromatiaceae family (Macarrón, 1998). Alternatively, Núñez-Cardona et al. (2008) reported data on the composition of fatty acids extracted from massive cultures of Amoebobacter roseus (DSM 235), Chromatium vinosum DSM183 (Allochromatium vinosum), and a wild strain isolated (Bk18) of a high mountain lake in Colombia, all members of the Chromatiaceae family. Table 1 depicts the pattern of the fatty acid characteristics of some purple sulfur bacteria pertaining to the Chromatiaceae family.

\begin{tabular}{|c|c|c|c|c|c|c|c|c|c|c|c|c|}
\hline Strain & C12:0 & C13:0 & C14:0 & C16:0 & C16:1 & aC17:0 & C17:0 & C18:0 & C18:1 & C20:1 & Sum $(\%)$ & Ref. \\
\hline Amoebobacter roseus DSM $235^{*}$ & & & 0.91 & 18.99 & 29.72 & & & 2.42 & 44.17 & 0.57 & 96.8 & 1 \\
\hline Amoebobacter roseus DSM 235 & 2.04 & 0.45 & 0.37 & 12.87 & 26.86 & 2.29 & 0.4 & 0.35 & 49.65 & 0.69 & 95.3 & 2 \\
\hline Amoebobacter sp. Bk18 & 1.83 & 0.29 & 0.33 & 12.41 & 27.67 & 2.31 & 0.3 & 0.68 & 47.58 & 0.54 & 93.4 & 2 \\
\hline Chromatium gracile DSM $203^{*}$ & & & 0.25 & 16.29 & 27.69 & & & 1.84 & 51.08 & 0.26 & 97.4 & 1 \\
\hline Chromatium gracile BF7200* & & & 0.6 & 19.34 & 25.69 & & & 3.04 & 47.58 & 0.68 & 96.9 & 1 \\
\hline Chromatium minus 1211 & & & 0.3 & 20.5 & 30.4 & & & 1.2 & 43.8 & & 96.2 & 3 \\
\hline Chromatium purpuratum BN 5500 (5\% salts) & & & 0.6 & 30.3 & 28.2 & & & 1.7 & 38.5 & 0.2 & 99.5 & 3 \\
\hline Chomatium vinosum ATCC $17899^{*}$ & & & 0.61 & 19.68 & 34.48 & & & 2.8 & 38.74 & 0.18 & 96.5 & 1 \\
\hline Chromatium vinosum DSM 183 & 1.25 & 0 & 0.79 & 13.62 & 31.77 & 0 & 0.27 & 0 & 47.14 & 0.43 & 94.8 & 2 \\
\hline Chromatium vinosum $\mathrm{D}$ & & & 0.7 & 18.9 & 36.2 & & & 0.7 & 39.3 & & 95.8 & 3 \\
\hline Chromatium vinosum $\mathrm{D}$ & & & + & 28.7 & 32.6 & & & + & 38.7 & & 100.0 & 3 \\
\hline Chromatium warmingii 6512 & & & 1.3 & 25.7 & 36.5 & & & 0.8 & 32.3 & & 96.6 & 3 \\
\hline Thiocapsa roseopersicina 6311 & & & 0.4 & 22.1 & 25.4 & & & 0.9 & 43.8 & & 92.6 & 3 \\
\hline Thiocapsa roseopersicina 9314 & & & + & 20 & 28 & & & + & 45 & & 93.0 & 3 \\
\hline Thiocapsa sp. & & & tr. & 19.7 & 27.9 & & & 2 & 34.6 & & 84.1 & 4 \\
\hline Thiocapsa sp. 5811* & & & 1.04 & 19.46 & 27.64 & & & 4.87 & 44.07 & 0.34 & 97.4 & 1 \\
\hline Thiocapsa sp. BF $6400^{*}$ & & & 0.8 & 17.42 & 19.8 & & & 2.22 & 55.12 & 0.9 & 96.3 & 1 \\
\hline Thiocystis gelatinosa 2611 & & & 0.6 & 22.9 & 30.5 & & & 1.2 & 39.5 & & 94.7 & 3 \\
\hline Thiocystis gelatinosa DSM 215* & & & 1.28 & 24.19 & 36.07 & & & 2.55 & 33.63 & 0 & 97.7 & 1 \\
\hline
\end{tabular}

Table 1. Fatty acid composition of different strains of photosynthetic purple sulfur bacteria (Chromatiaceae family) *Linked to phospholipids, 1) Macarrón (1998), 2) Núñez-Cardona et al. (2008), 3) Data cited from Imhoff \& Bias-Imhoff (1995), 4) Fredrickson et al. (1986). Ref=reference.

Recently, Sucharita et al. (2010) analyzed the fatty acid composition of the strains Maricromatium fluminis JA418, Mch. indicum JA100, Mch. purpuratum DSM 1591 (or 
Chromatium purpuratum DSM 1591) and Mch. gracile DSM 203 (Chromatium gracile DSM 203). They concluded that C16:0, C16:1 and C18:1, are the main fatty acids for these strains and also they detailed the minor fatty acid components but only in Mch.indicum (Table 2).

\begin{tabular}{|c|c|c|c|c|c|}
\hline Fatty acid & JA418 & JA124 & JA100 & DSM203 & DSM 1591 \\
\hline C12:0 & 2.4 & 12.5 & 3 & 9.2 & 1.8 \\
\hline C12:0 anteiso & - & - & 2 & - & - \\
\hline C14:0 anteiso & - & - & 3.1 & - & - \\
\hline C14:0 & - & - & 1.8 & - & - \\
\hline $\mathrm{C} 14: 02-\mathrm{OH}$ & - & - & 2.1 & - & - \\
\hline C16:0 & 25.7 & - & 2.7 & 15.6 & 20.5 \\
\hline $\mathrm{C} 16: 0 \mathrm{nOH}^{*}$ & - & - & 1.7 & - & - \\
\hline C16:0iso & - & - & 1.8 & - & - \\
\hline $\mathrm{C} 16: 1 w 9 \mathrm{c}$ & - & - & 3.6 & - & - \\
\hline C18:0 & - & - & - & 4.2 & - \\
\hline $18: 1$ iso $\mathrm{OH}$ & - & - & 3.7 & - & - \\
\hline C18:3w 6,9,12c & - & 33.4 & 2.7 & - & - \\
\hline $\mathrm{C} 16: 1 w 7 c$ & 28.4 & - & - & 10.5 & 29.4 \\
\hline C16:1w $7 c$ alcohol & - & - & - & 2.1 & - \\
\hline $\mathrm{C} 18: 1 w 7 c$ & 37 & - & 1.8 & 49.2 & 40.4 \\
\hline $\mathrm{C} 18: 1 w 5 c$ & 0.3 & 54 & 68.5 & - & - \\
\hline Total (\%) & 93.8 & 99.9 & 98.5 & 90.8 & 92.1 \\
\hline
\end{tabular}

Table 2. Fatty acids (\%) of Marichromatium genus (Sucharita et al., 2010).

According to Janse (1997), in Gram-negative bacteria, the most frequent saturated fatty acids are $\mathrm{C} 16: 0, \mathrm{C} 18: 0$, and C14:0; the most common unsaturated are C16:1 cis or trans 9 and C18:1 cis or trans 11. The hydroxyl acids, which are part of lipid A that contains several 3-OH fatty acid chains, can be used as markers for detecting Gram-negative bacteria (Li et al., 2010). This fact has been reported only in Mch. indicum and analyzed using the MIS system by Sucharita et al. (2008).

It is evident that information available on fatty acids of purple photosynthetic sulfur bacteria (Chromatiaceae family) has serious limitations, but it is also clear that their main cellular components are C16:0, C16:1 and C18:1, as has been reported by Imhoff (2008).

\subsubsection{Fatty acids in Ectothiorhodospiraceae family}

Table 3 includes information on species of Ectothiorhodospira, Halorhodospira, and Thiorhodospira genera, the last two have been analyzed very recently, and fatty acids with chains between 14 and 22 carbon atoms have been observed. Fatty acid C20:1 was only detected in Ec. shaposhnikovii and Halorhodospira halophila (DSM 244) and C22:0 in Hal. halophila BN 9626. This information reveals that major fatty acids for the Ectothiorhospiraceae family are C18:1 and C16:0 except for Thiorhodospira sibirica which has more C16:1 than C16:0.

Fatty acid analyses of Ectothiorhodospiraceae family species have been reported on Ectothiorhodospira halophila 9630 (Assellineau \& Trüper, 1982) and Ec. halophila 9628, both grown in culture media at different salt concentrations (Imhoff \&Thiemann, 1991), and Ec. halophila SL1 (Imhoff, unpublished data, cited in Imhoff \& Bias-Imhoff, 1995), Ec. halochloris 9850 (Asselineau \& Trüper, 1982; Imhoff, 1988), Ec. abdelamalekii 9840 (Asselineau \& Trüper, 1982; Imhoff unpublished data, cited in Imhoff \& Bias-Imhoff, 1995), and Ec. mobilis grown at different temperatures (Imhoff \& Thiemann, 1991). Additionally, fatty acids of Ec. shaposhnikovii (Asselineau \& Trüper, 1982; Imhoff, unpublished data cited in Imhoff \& Bias- 
Imhoff, 1995) and Ec. vacuolata DSM 2111 (Asselineau \& Trüper, 1982; Imhoff, unpublished data) have been analyzed.

\begin{tabular}{|c|c|c|c|c|c|c|c|c|c|c|c|c|}
\hline Strain/fatty acid & C12:0 & C14:0 & C16:1 & C16:0 & C18:1 & C18:0 & $\mathrm{C} 19: 0 \mathrm{~d} 8,9^{* * *}$ & ${ }^{*}$ Cyc 19:0 & C20:1 & $\mathrm{C} 22: 0$ & Sum & Reference (condition) \\
\hline Ec. halophila 9628 & & 0.8 & 1.2 & 25.4 & $63.8^{*}$ & 8.6 & & & & & 36 & $1 \quad(10 \%$ salts $)$ \\
\hline Ec. halophila 9628 & & 0.7 & 1.6 & 22 & $69.4^{*}$ & 5.6 & & & & & 29.9 & $1 \quad(20 \%$ salts $)$ \\
\hline Ec. halophila 9628 & & 0.9 & 1.2 & 24.9 & $63.8^{*}$ & 6.9 & & & & & 33.9 & 1 (30\% salts) \\
\hline Ec. halophila SL1 & & & 0.9 & 11.4 & 8.7 & 63.8 & & 7.3 & & & 92.1 & 1 \\
\hline Ec. halophila 9630 & & 1 & 1 & 16 & 33 & 15 & & 31 & & & 97 & 1 \\
\hline Ec. halochloris 9850 & & 0.4 & 0.4 & 18.9 & 69.7 & 7.5 & & 1 & & & 97.9 & 2 \\
\hline Ec. halochloris 9850 & & $\operatorname{tr}$ & $\operatorname{tr}$ & 19 & 51 & 7 & & 18 & & & 95 & 1 \\
\hline Ec. abdelmaleki 9840 & & 0.3 & 1.8 & 24.7 & 58.9 & 5.4 & & 6.3 & & & 97.4 & 1 \\
\hline Ec. abdelmaleki 9840 & & 0.5 & 3 & 16 & 57 & 4 & & 10 & & & 90.5 & 1 \\
\hline Ec. mobilis 9903 & & 0.2 & 5.5 & 14 & 72.3 & 4.8 & & $\operatorname{tr}$ & & & 96.8 & $1 \quad\left(5 \%\right.$ salts, $\left.27^{\circ} \mathrm{C}\right)$ \\
\hline Ec. mobilis 9903 & & 0.2 & 4.6 & 20.7 & 62.2 & 9.6 & & 0.4 & & & 97.7 & $1 \quad\left(5 \%\right.$ salts, $36^{\circ} \mathrm{C}$ \\
\hline Ec. mobilis 9903 & & 0.5 & 3.4 & 23.1 & 59.7 & 10.9 & & 0.3 & & & 97.9 & $1 \quad\left(5 \%\right.$ salts, $\left.42^{\circ} \mathrm{C}\right)$ \\
\hline Ec. shaposhnikovii N1 & & $\operatorname{tr}$ & 8 & 17 & 68 & $\operatorname{tr}$ & & nd & & & 93 & 1 \\
\hline Ec. shaposhnikovii $\mathrm{N} 1$ & & 0.1 & 6.8 & 13.1 & $74.7^{*}$ & 2 & & & & & 22 & 1 \\
\hline Ec. vacuolata DSM 2111 & & & 4.8 & 15.3 & $73.5^{*}$ & 2.4 & & & & & 22.5 & 1 \\
\hline Ec. vacuolata DSM 2111 & & $\operatorname{tr}$ & 6 & 20 & 60 & 7 & & nd & & & 93 & 1 \\
\hline Ectothiorhodospira salini & & & 8 & 18.0 & 56 & & & 12 & & & 94 & 3 \\
\hline Ec. magna & & & 12.58 & 14.2 & 70.58 & 1.53 & & N/D & & & 86.31 & 4 \\
\hline Ec. shaposhnikovii & $1.3-1.7$ & & $4.1-4.6$ & $24.4-26.4$ & $57.1-59.0$ & $5.6-6.8$ & & N/D & & & $92.5-98.5$ & 4 \\
\hline Ec. vacuolata & N/D & & 3.6 & 21.6 & 65.3 & 5.5 & & N/D & & & 96 & 4 \\
\hline Ec. shaposhnikovii** & & 2.5 & 4.6 & 21.6 & 59.4 & 5.6 & $\operatorname{tr}^{*}$ & & 0.5 & & 94.2 & 5 \\
\hline Ec. mobilis ${ }^{* *}$ & & 1.2 & 2.7 & 35.7 & 16.5 & 7.6 & 33.8 & & & & 97.5 & 5 \\
\hline Hal. halophila BN9626** & & 4.6 & $\operatorname{tr}$ & 18 & 54.9 & 13.9 & 2.9 & & & 3.9 & 98.2 & 5 \\
\hline Hal. halophila DSM244 ** & & 0.3 & 0.6 & 10.8 & 62.8 & 11.7 & 5.8 & & 1.8 & & 93.8 & 5 \\
\hline Thiorhodospira sibirica & & 0.3 & 21.3 & 18.1 & 52.9 & 3.7 & & & & & 96.3 & 4 \\
\hline
\end{tabular}

Table 3. Fatty acids recorded in Ectothiorhodospiraceae family members. 1) Imhoff \& Thieman (1991), 2) Imhoff (1988), 3) Ramana et al. (2010), 4) Bryanseva et al. (2010), 5) Yakimov et al. (2001). N/D=not determined, nd=not detected, $\operatorname{tr}=$ less 0.05\%, * $\mathrm{C} 18: 1$ included $C y c 19,{ }^{* *}$ Values are percentages of the total fatty acids isolated from cellular phospholipids, ***Phospholipid fatty acid. Ec. Ectothiorhodospira, Hal. Halorhodospira

Information available on fatty acid profiles of Ectothiorhodospira genus members, shows that the major fatty acids for the analyzed species are C16:0 (11.4-35.7\%) and the C18:1 $(16.5-74.7 \%)$. They also contain C14:0 (traces-2.5\%), C16:1 (traces-12.5\%), and Cyc19:0 (tr$31 \%)$; although in some strains, the latter has not been detected or is added to its precursor, C18:1.

\subsubsection{Fatty acids in Chlorobiaceae family}

Regarding the fatty acid composition of green sulfur bacteria pertaining to the Chlorobiaceae family, strains of the Chlorobium and Pelodyction genera have been analyzed (Table 4). It is important to note that Pelodyction was reclassified, and actually is a member of the Chlorobium genus (Imhoff \& Thiel, 2010).

In green photosynthetic sulfur bacteria, the presence of at least 12 fatty acids with 12 to 18 carbon atoms has been reported, and C14:0 (traces-27.10\%), C16:1 (37.3-64.0\%), C16:0 (3.5229\%), C15:0 (2.74-14.14), C18:1 (traces-15.59\%), C18:0 (traces-3.30\%), and Cyc17:0 (0.70-21\%) 
have been cited as the major fatty acids. It is possible that the information reported in table 4 , which contains the fatty acid composition of green bacteria, is the only information of this type available at the present.

\begin{tabular}{|c|c|c|c|c|c|c|c|c|c|c|c|c|c|}
\hline Strain & C12:0 & C14:0 & C14:1 & $a \mathrm{C} 15: 0$ & C15:0 & C16:1 & C16:0 & $a \mathrm{C} 17: 0$ & Сус 17:0 & C17:0 & C18:1 & C18:0 & Ref. \\
\hline Cb. limicola f.thiosulf. 6330 & & 13.00 & 2 & & & 57 & 17 & & 3 & & & $\operatorname{tr}$ & 1 \\
\hline Cb. limicola f.thiosulf. 6230 & & 21.00 & 2 & & & 43 & 10 & & 21 & & 1 & $\operatorname{tr}$ & 1 \\
\hline Cb. limicola f.thiosulf. 6230 & 1.1 & 27.10 & & & & 37.3 & 20.3 & & 7.3 & & 3.1 & $\operatorname{tr}$ & 2 \\
\hline \multicolumn{2}{|l|}{$\mathrm{Cb}$. phaeobacteroides BF8600* } & 7.65 & & 0.48 & 5.44 & 44.98 & 26.81 & 0.34 & & 0.33 & 5.47 & 2.07 & 3 \\
\hline Cb.phaeobacteroides 2430 & & 16.00 & 1 & & & 64 & 15 & & 1 & & 1 & $\operatorname{tr}$ & 1 \\
\hline Cb.phaeovibrioides 2631 & & 10.00 & $\operatorname{tr}$ & & & 51 & 29 & & 2 & & 2 & $\operatorname{tr}$ & 1 \\
\hline$C b$. vibrioides f.thiosulf. 1930 & & 12.00 & $\operatorname{tr}$ & & & 52 & 23 & & 3 & & 2 & 1 & 1 \\
\hline Cb. vibrioides f.thiosulf. 8327 & 2.1 & 24.40 & & & & 42.8 & 23 & & 0.7 & & 1.2 & 3.3 & 2 \\
\hline$C b$. vibrioides f.thiosulf. 2230 & 2.9 & 23.80 & & & & 43.4 & 22.1 & & 2.6 & & 3.1 & $\operatorname{tr}$ & 2 \\
\hline Cb.vibrioforme BF8200* & & 8.80 & 0.19 & & 0.83 & 46.59 & 19.46 & & & 0.39 & 15.59 & 2.41 & 3 \\
\hline Cb. limicola DSM $245^{*}$ & & 16.61 & 0.3 & & 14.14 & 38.26 & 19.93 & \multicolumn{2}{|l|}{-} & 0.28 & 2.13 & 1.6 & 3 \\
\hline Cb.limicola BF8010* & & 11.10 & 0.5 & 0.48 & 9.38 & 41.81 & 24.25 & 0.25 & & 0.22 & 2.82 & 0.87 & 3 \\
\hline Chlorobium sp. Chlo* & & $\operatorname{tr}$ & & 0.59 & 2.74 & nd & 3.52 & & 6.09 & 7.3 & 7.37 & $\operatorname{tr}$ & 4 \\
\hline Pelodictyon luteolum 2530 & & 14.00 & 1 & & & 47 & 21 & & 11 & & $\operatorname{tr}$ & $\operatorname{tr}$ & 1 \\
\hline
\end{tabular}

Table 4. Fatty acids of green photosynthetic sulfur bacteria. 1) Kenyon \& Gray (1974), 2)

Knudsen et al. (1982), 3) Macarrón (1998), 4) Fredrickson et al. (1986). *Linked to phospholipids, $\mathrm{Cb}$. Chlorobium; $f$. thiosulf form thiosulfatophilum, $\operatorname{tr}=\operatorname{trace}$, Ref.=reference.

\subsection{Fatty acids as a chemotaxonomic tool in purple and green sulfur bacteria}

With the development of techniques and equipment to analyze the chemical properties of living organisms, new tools arose that markedly helped choose those properties that would enable the distinction, separation, and, finally, the classification of microorganisms (Stanier, 1968), providing data for more in-depth studies on their phylogenetic relations.

One of the first authors to propose the use of the chemical characteristics of microorganisms for taxonomic purposes was Wolochow (1959 cited in Abel et al., 1963). He suggested that microorganisms could be differentiated from "higher" organisms based on their chemical properties, as these properties are unique, providing a better theoretical basis for their classification. This concept was later amplified by Abel et al. (1963), who pointed out the importance of qualitative and quantitative analyses of several selected compounds, which would lead to a method for differentiation among species. These authors suggested that the chemical composition of living organisms could be regulated by natural or evolutionary relations and that this information could be obtained whenever culturing bacteria under defined conditions.

Based on previous studies performed by Scheuerbrandt \& Bloch (1962) using liquid gas chromatography, the anaerobic and aerobic routes for the biosynthesis of fatty acids were proposed, enabling the distinction between prokaryotic and eukaryotic microorganisms to be made. It was set forth that no microorganisms can use both routes at the same time and that the presence of polyunsaturated fatty acids is an evolutionary event. This idea was later revised by Erwin \& Bloch (1964), who stated that the composition of lipid molecules is determined not only genetically but also by the conditions of the environment; hence, 
factors such as temperature, nutritional and culture conditions (aerobic, anaerobic, etc.) can modify the lipidic pattern of living organisms.

From the start of bacterial classification it was recognized that structural characteristics by themselves were not enough for successful classification (Cohn 1872, cited in Stanier, 1968). Variations in the composition of fatty acids of bacterial cells have been used for their identification since the introduction of gas chromatography more than 50 years ago by Abel et al. (1963). Both the qualitative and quantitative composition was useful in differentiating microorganisms (Sasser, 2001). In bacteria, these cellular components have the advantage of not being present in their plasmids (Boom \& Cronan Jr., 1989).

According to De Gelder (2008), chemotaxonomic techniques provide phenotypic properties, one of which is the fatty acid methyl ester (FAME) analysis that determines the fatty acid composition of the membrane and outer membrane of cells. Using this technique, fatty acids are extracted from cell hydrolysates and derivatized to volatile methyl esters which can be detected by gas chromatography. FAME allows grouping of many organisms according to the similarity of their fatty acid pattern, which is useful for identification. Quantitative data on bacterial fatty acid composition have allowed for the distinction and separation of families, genera, and even species.

In heterotrophic bacteria, the fatty acid composition has been widely studied for chemotaxonomic purposes. However, for purple and green photosynthetic sulfur bacteria, the use of this taxonomic tool is limited; most of the available data focus on major, aside from having been performed in limited species. Some of the data have been included in the description of new species, dealing mostly with the major fatty acids and with no attention given to the minor ones, despite that the latter could provide more information to separate the genera, and perhaps their species, providing more power to the use of this chemotaxonomic tool.

Currently published data on photosynthetic bacteria fatty acid composition are incomplete; data do not mention aspects like age of the bacterial culture and incubation conditions (temperature, light, etc). They neither specify the analytical techniques such as the extraction method, the total area of chromatogram integration, size of the samples, etc. nor how data were handled (normalization or standardization of data, etc.).

These deficiencies have made it quite difficult to compare information between diverse laboratories; consequently, the use of this tool becomes limited for chemotaxonomic classification and for its possible application to the phylogeny study of these ancestral photosynthetic microorganisms.

The advancement of knowledge on fatty acids in photosynthetic bacteria seems to have slowed down in the last decade, and with some exceptions, species descriptions do not include their fatty acid pattern. This is due to the fact that it is stated in the standard recommendations for the description of new species of anoxygenic photosynthetic bacteria, proposed by Imhoff \& Caumette (2004), which were established in accordance with 30b of the International Code of Nomenclature of Bacteria and the support of the International Committee on Systematics of Prokaryotes, that fatty acid analysis is optional for the identification of photosynthetic bacteria. 
In this respect, Tindall et al. (2010) presented a series of tests that must be used to determine the location of a strain as a member of an existing taxon, and they provide the methodologies and how those methodologies should be used and implemented; among these is the chemical characterization of cells with consideration of fatty acid composition for this objective. As a general recommendation, they point out the need to study the chemotaxonomic features of the most closed taxa for their comparison, particularly when new genera are being proposed.

With the aim of achieving reproducible profiles, Janse (1997) proposed a series of elements not only to apply a determined technique, but also to analyze the generated information. These are as follows: 1) use of cells of the same age, 2) a standard culture medium for both aerobic and anaerobic bacteria, 3) a gas chromatograph with a flame ionization detector (FID), an integrator, and a computer with a printer, 4) fatty acid solutions of known composition (standard), and 5) a statistical program for cluster analysis and analysis of its main components. Aside from the aforementioned, De Gelder (2010) points out the need to count with an extensive FAME database. With the Microbial Identification System (MIS), the techniques and methods for the analysis and identification of fatty acids, and their statistical analysis are well standardized and automated for heterotrophic bacteria. This system enables researchers to have, in a short time, accurate information on the composition and distribution of these chemical compounds in different microorganisms. By means of MIS, more than 300 fatty acids and related compounds (aldehydes, hydrocarbons, dimethyl acetyls) have been identified (Sasser, 2001).

The MIS system (MIDi Co) has been used for fatty acid analysis of non-photosynthetic bacteria and the description of species as in Rheinheimera soli (Ryu et al., 2008) and Alcalilimnicola halodurans (Yakimov et al., 2001), which are phylogenetically related to the Chromatiaceae and Ectothiorhodospiraceae families. Additionally, fatty acid profiles of purple non-sulfur bacteria have been obtained with the MIS system, an example being Rhodovulum phaeolacus (Lakshmi et al., 2011).

In photosynthetic purple sulfur bacteria, MIS has been applied to fatty acid analysis of different species, for example in different strains of Marichromatium (Sucharita et al., 2010) and Ectothiorhodospira (Bryantseva et al., 2010) genera. Nevertheless, one of the limitations of the MIS system is that it can only detect fatty acids with fewer than 20 carbons, and according to Tindall et al. (2010), the MIS system provides a comprehensive, but incomplete, database with some discrepancies that need to be clarified or compounds that are currently not included in the database.

Due to the variability in fatty acid analysis, the use of chromatographic techniques as taxonomic tools requires standardization of the culture conditions, the physiological age of cells, and the analysis techniques to obtain reproducible results. The need for a standard technique for fatty acid analysis of sulfur photosynthetic bacteria is real, and a technique for this purpose is included at the present chapter.

\section{Fatty acid analysis of photosynthetic purple and green sulfur bacteria}

\subsection{Bacteria strains used for fatty acid analyses}

Fatty acid analyses were done with collection strains (as reference) of phototrophic purple sulfur bacteria (Chromatiaceae family) these were: Amoebobacter purpureus (DSM 4197), 
Chromatium purpuratum (DSM 1591), Chromatium salexigens (DSM 4395), Chromatium tepidum (DSM 3771), Chromatium vinosum (DSM 185), Thiocapsa halophila (DSM 6210), Thiocapsa marina (DSM 5811), and two strains of green phototrophic sulfur bacteria (Chlorobiaceae family): Chlorobium limicola (DSM 249) and Chlorobium phaeobacteroides (DSM 266). In addition, nine wild strains of purple and one green photosynthetic sulfur bacteria, isolated from the coastal lagoon Tampamachoco (Veracruz, Mexico) were included.

For the Isolation of wild strains of phototrophic purple sulfur bacteria, water samples from Tampamachoco lagoon (Veracruz, México) were collected using a 5-L van Dorn sampler. Test tubes containing Chromatiaceae and Chlorobiaceae specific culture media (Pfennig \& Trüper, 1981; Nuñez-Cardona et al., 2008) were enriched with the water samples. Culture medium composition was: $1.0 \mathrm{~g} \mathrm{KH}_{2} \mathrm{PO}_{4}, 0.5 \mathrm{~g} \mathrm{NH}_{4} \mathrm{Cl}_{2}, 0.40 \mathrm{~g} \mathrm{MgCl} \cdot 6 \mathrm{H}_{2} \mathrm{O}, 0.05 \mathrm{~g} \mathrm{CaCl}_{2}$. $6 \mathrm{H}_{2} \mathrm{O}, 1.0 \mathrm{~mL}$ trace element solution SL12, $1.0 \mathrm{~mL}$ vitamin $\mathrm{B}_{12}\left(2.0 \mathrm{mg} \mathrm{L}^{-1}\right.$ distilled water),

\begin{tabular}{|c|c|c|c|c|c|}
\hline Code & Strain & Origin & Main pigments & Shape & $(\mathrm{NaCl} \%)$ \\
\hline DSM 4197 & Amb.purpureus (1) & Schleinsee (Germany) & Bchl $a$, ok & Coccus & 0 \\
\hline T1f6 & Amoebobacter sp. & TL México & Bchl $a, s p$ & Coccus & 2 \\
\hline DSM 1591 & Chr.purpuratum & Sea sponge & Bchl $a$, ok & Rods & 5 \\
\hline DSM 4395 & Chr. salexigens & GS (Camargue France) & Bchl $a, s p, l y, r h$ & Rods & 7 \\
\hline DSM 3771 & Chr. tepidum & YPN (USA) & Bchl $a, s p, l y, r h$ & Rods & 0 \\
\hline DSM 185 & Chr. vinosum & Pond & Bchl $a, s p, l y, r h$ & Rods & 0 \\
\hline T9s60 & Chromatium sp. & TL México & Bchl $a, s p$ & Rods & 2 \\
\hline T9s62 & Chromatium sp. & TL México & Bchl $a$, ly & Rods & 2 \\
\hline T9s64 & Chromatium sp. & TL México & Bchl $a$, ly & Rods & 2 \\
\hline T9s642 & Chromatium sp. & TL México & Bchl $a, s p$ & Rods & 2 \\
\hline T7s9 & Chromatium sp. & TL México & Bchl $a$, ly & Rods & 2 \\
\hline T9s68 & Chromatium sp. & TL México & Bchl $a$, ly & Rods & 2 \\
\hline T11rosa & Thiocapsa sp. & TL México & Bchl $a, s p$ & Coccus & 2 \\
\hline T11s & Thiocapsa sp. & TL México & Bchl $a, s p$ & Coccus & 2 \\
\hline DSM 6210 & Tc. halophila & GS (Camargue France) & Bchl $a$, ok & Coccus & 7 \\
\hline DSM 5811 & Tc. marina & LP France & Bchl $a$, ok & Rods & 5 \\
\hline DSM 249 & Chlorobium limicola & THS, USA & Bchl $c, c b$ & Rods & 0 \\
\hline DSM 266 & Cb. phaeobacteroides & LB, Norway & Bchl $e$, irt & Rods & 0 \\
\hline $\mathrm{T} 11 \mathrm{~S}$ & Chlorobium sp. & TL México & Bchl $c, c b$ & Rods & 2 \\
\hline
\end{tabular}

Table 5. Purple photosynthetic sulfur bacteria strains used for fatty acid analysis.

DSM German Collection of Microorganisms and Cell Culture, Amb. Amoebobacter, Cb. Chlorobium, Chr Chromatium, Tc Thiocapsa. TL=Tampamachoco Lagoon, GS=Giraud Saltens, YNP=Yellowstone National Park. THS=Tassajara Hot Spring (USA), LB=Lake Blankvann, Bchl bacteriochlorophyll, $o k$ okenone, $c b$ chlorobactene, $s p$ spirilloxanthin, ly lycopene, $r h$ rhodopinal, irt isorenieratene, $\mathrm{NaCl}(\%)=$ Optimal salinity requirement. 
$30.0 \mathrm{~mL}$ sodium bicarbonate solution ( $5 \%$ distilled water), $6.0 \mathrm{~mL} \mathrm{Na} \mathrm{S}^{2} 9 \mathrm{H}_{2} \mathrm{O}$ ( $6 \%$ distilled water), and distilled water (ca. $950 \mathrm{~mL}$ ) up to $1 \mathrm{~L}$, and adjusted to $\mathrm{pH}$ 7.3. For Chlorobium species, the same medium was used but $\mathrm{Na}_{2} \mathrm{~S} \cdot 9 \mathrm{H}_{2} \mathrm{O}$ was increased to $10.0 \mathrm{~mL}$; solution SL10 and $\mathrm{pH} 6.8$ were used. Test tubes were kept at room temperature under constant illumination by $60-\mathrm{W}$ incandescent and fluorescent light bulbs placed at $20-25 \mathrm{~cm}$, were used for growth of Chromatiaceae and Chlorobiaceae, respectively (van Niel, 1971). Agar shake technique on semisolid medium sealed with oil paraffin was used to isolate and purify photosynthetic purple and green sulfur bacteria (Pfennig \& Trüper, 1981). Pure cultures were verified by optical microscope observations.

Table 5 contains the list of the cultures and collection strains used for fatty acid analysis, general characteristics (main pigments and cell forms), and optimal salinity requirements for each one. At the present document, all the bacteria strains are cited as it is in the original papers or as they were handled. This is because constantly photosynthetic bacteria are reclassified and their names also change.

\subsection{Culture conditions}

All strains were grown anaerobically by triplicate in $1500-\mathrm{mL}$ bottles with metal screw caps and autoclavable rubber seals containing the specific culture medium described before; $\mathrm{pH}$ between 7.0-7.5 for Chromatiacea and 6.8 for green sulfur bacteria. Liquid cultures of purple sulfur bacteria were illuminated constantly by incandescent light bulbs (2000 lux) and green sulfur bacteria were exposed to fluorescent light bulbs. Incubation temperature was $23{ }^{\circ} \mathrm{C}$ except for the thermophilic strain Chr. tepidum $\left(43^{\circ} \mathrm{C}\right)$. Enough biomass of each culture was attained with a sodium sulfide solution neutralized with hydrochloric acid, added almost daily when sulfur was not present in cultures the latter was detected by the use of lead acetate paper (Merck).

After 15 days of incubation and without sulfur in the liquid cultures, the cells were concentrated by centrifugation $\left(5000-10,000 \mathrm{rpm}\right.$ at $\left.5{ }^{\circ} \mathrm{C}\right)$. Cultures of Amoebobacter and Thiocapsa were centrifuged at 10,000 rpm since it was ratter difficult to concentrate the cells. Once the cultures were concentrated, the cells were frozen at $-20{ }^{\circ} \mathrm{C}$, for further lyophilization.

\subsection{Fatty acid analysis by gas chromatography}

\subsubsection{Sampling conditions}

Temperature, age of the cells, as well as the composition of the medium, affect cells fatty acid composition and limits the comparison of the results among different laboratories and the application of these cellular components as a chemotaxonomic tool. Few reports deal with the importance of the size and sample conditions (dry or wet) for fatty acids analysis. It has been proposed that for heterotrophic bacteria, less than $40.0 \mathrm{mg}$ of wet weight were enough (Sasser, 2001). It has also been indicated that $1.0 \mathrm{mg}$ of dry weight (Brondz \& Olzen, 1986) or a single colony could be enough for fatty acids analysis (Buyer, 2002). In the case of phototrophic sulfur bacteria, Tacks and Holt (1971) used 10-15 g of wet weight of Thiocapsa floridiana (Thiocapsa roseopersicina).

At the present work, and for the sake of reproducibility it was used cells of the same age (Janse, 1997; Sasser, 2001); grown in standard conditions (as previously described) and fatty 
acid analyses were done weighing $500 \mathrm{mg}$ and $250 \mathrm{mg}$ of dry cells, for purple and green photosynthetic sulfur bacteria, respectively.

\subsubsection{Fatty acid analysis}

For fatty acid analysis, fat present in the freeze-dried cells (three different samples of the same strain) was saponified, followed by diazomethane derivatization (Sigma N-nitrosomethylurea), and evaporation with nitrogen gas. Identification of fatty acids was accomplished by comparison of the retention times with standard mixtures of fatty acid methyl esters. Fatty acids final identification was done by gas chromatography and mass spectrometry (Muñoz et al., 1996; Núñez-Cardona et al., 2008). Details of these techniques are described below.

\subsubsection{Extraction of lipids}

Each sample was treated with $2.0 \mathrm{~mL}$ benzene and $8.0 \mathrm{~mL}$ of $\mathrm{KOH}$ solution $(5.0 \mathrm{~g} / 100 \mathrm{~mL}$ methanol) and containing $5 \%(\mathrm{w} / \mathrm{v})$ potassium hydroxide in a screw-cap test tube $(14 \mathrm{X} 120$ $\mathrm{mm}$ ) fitted with a Teflon-lined cap and heated in a cover bath at $80{ }^{\circ} \mathrm{C}$ during 4 hours. The samples were cooled at room temperature and were acidified with a solution of $\mathrm{H}_{2} \mathrm{SO}_{4}(20 \%$ $\mathrm{v} / \mathrm{v}$ ) to $\mathrm{pH} 1$, this was verified with $\mathrm{pH}$ paper test. Diethyl ether was added to extract lipids and it was added water to wash the extracts until neutral and the clean separated ether was evaporated using a nitrogen gas atmosphere.

\subsubsection{Preparation of methyl esters}

The lipids were methylated using diazomethane, each sample was prepared with $2.0 \mathrm{~g} \mathrm{~N}$ Nitroso-N-methylurea (Sigma) dissolved in a precooled solution containing $30.0 \mathrm{~mL}$ of diethyl ether, $2.0 \mathrm{~g} \mathrm{KOH}$ and $6.0 \mathrm{~mL}$ distilled water. The mixture was stirred for 5 to 10 minutes, it was removed the supernatant and placed in a new tube cooled in ice containing potassium hydroxide pellets. This solution must be conserved to $-80{ }^{\circ} \mathrm{C}$ and handled in a hood because diazomethane is very toxic. At the end, $10 \mathrm{ml}$ of diazomethane was added into each tube with the dried lipids and methylation was achieved within 10-20 minutes; after this time, the content was evaporated at $40^{\circ} \mathrm{C}$ in a water bath.

\subsubsection{Fatty acid methyl ester analysis by gas chromatography}

N-hexane (0.04-1.0 mL) was added to the dried extracts and $2.0 \mu \mathrm{L}$ were injected in a gas chromatograph supported by a silica capillary column $(15 \mathrm{~m} \times 0.25 \mathrm{~mm}$ I.D.) with crosslinked methyl silicone (HP-1, Hewlett-Packard) as stationary phase. The column was inserted in an HP-5890A gas chromatograph equipped with a flame ionization detector. The column was programmed at 175 to $300^{\circ} \mathrm{C}$ for 15 minutes. Injector and detector temperatures were 275 and $300{ }^{\circ} \mathrm{C}$, respectively. The carrier gas was helium with a flow rate of approximately $1.0 \mathrm{~mL} / \mathrm{min}$ and the split ratio was approximately 1:50. The chromatograms were integrated by using a HP3396 Series II Integrator. Identification of fatty acids was accomplished by comparison of the retention times with standard mixtures of fatty acid methyl esters.

\subsubsection{Gas chromatography-mass spectrometry analysis}

Fatty acids were subjected to gas chromatography-mass spectrometry, using an HP-5890 gas chromatograph attached to a HP5989X quadripole mass spectrometer with a 
dimethylpolysiloxane column TRB1 $(30 \mathrm{~m})$. Injector and detector temperatures were $225^{\circ} \mathrm{C}$, and two ramps were used, one from $10^{\circ} \mathrm{C} / \mathrm{min}$ to $240^{\circ} \mathrm{C}$ and the other one from $40{ }^{\circ} \mathrm{C} / \mathrm{min}$ to $270{ }^{\circ} \mathrm{C}$. The injection mode was splitless, ca. 1:50.

\subsubsection{Reproducibility of fatty acid pattern}

With the aim of reaching reproducible data, the integration area of the fatty acid peaks was fixed to 1800 as minimal area and the extract of each sample was injected as many times to get a total area between $14 \times 10^{6}$ and $18 \times 10^{6}$ for purple sulfur and $7 \times 10^{6}$ for green photosynthetic sulfur bacteria.

To assess the reproducibility of the fatty acids pattern, the coefficient of variation (CV) was calculated; for this, it was used the peaks of each fatty acid generated in the chromatograms of the three independent samples of each strain. The standard deviation (of each peak that corresponds to one fatty acid) was calculated and divided by the mean and multiplied by 100, this was made following the recommendations of Bounsfield et al. (1983) and Rainey et al. (1994).

\subsection{Results and discussion}

With the technique applied for fatty acid analysis, it was possible to determine at least 90$99 \%$ of the total fatty acid composition from purple sulfur bacteria of the Chromatiaceae family. Data are the results of three different chromatograms from three different cultures of the same strain. The variation coefficient calculated for each fatty acid was less than $10 \%$; therefore, the results here presented have a high degree of reproducibility. Major and minor fatty acids for photosynthetic sulfur bacteria are given in Table 6.

\begin{tabular}{|c|c|c|c|c|c|c|c|c|c|c|c|c|c|}
\hline Strain & NI & C12:0 & C13:0 & C14:0 & C16:1 & C16:0 & aC17:0 & C17:0 & C18:1(7) & C18:1(9) & C18:0 & C20:1 & X (\%) \\
\hline DSM 4197 & 1.13 & 0.53 & 0.42 & 0.31 & 28.17 & 11.66 & 1.80 & 0.53 & 41.53 & 6.61 & 0.21 & 0.60 & 93.50 \\
\hline T1f6 & 1.10 & 1.36 & 0.48 & 0.43 & 24.43 & 14.53 & 2.34 & 0.35 & 43.03 & 6.72 & 1.25 & 0.75 & 96.77 \\
\hline DSM 5811 & 1.86 & 0.49 & 0.43 & 0.29 & 27.64 & 12.05 & 0.18 & 0.04 & 41.72 & 6.14 & 1.84 & 0.70 & 93.38 \\
\hline DSM1591 & 1.78 & 0.47 & 0.00 & 0.19 & 30.18 & 6.59 & 0.00 & 0.37 & 45.10 & 4.62 & 3.37 & 0.83 & 93.50 \\
\hline DSM 4395 & 1.41 & 0.74 & 0.00 & 0.81 & 17.34 & 16.74 & 0.00 & 0.29 & 51.90 & 4.76 & 2.54 & 0.77 & 97.30 \\
\hline DSM 3771 & 1.11 & 0.33 & 0.00 & 0.41 & 16.17 & 25.86 & 0.00 & 0.55 & 36.27 & 7.11 & 4.81 & 2.44 & 95.06 \\
\hline DSM185 & 0.94 & 0.13 & 0.00 & 0.76 & 31.77 & 15.90 & 0.00 & 0.08 & 36.92 & 10.04 & 0.00 & 0.60 & 97.14 \\
\hline T9s60 & 2.34 & 0.93 & 0.00 & 0.25 & 26.38 & 14.23 & 0.00 & 0.30 & 44.00 & 6.01 & 1.74 & 0.68 & 96.86 \\
\hline T9s62 & 1.98 & 0.72 & 0.00 & 0.24 & 27.14 & 11.81 & 0.00 & 0.42 & 45.80 & 5.85 & 1.85 & 0.62 & 96.43 \\
\hline T9s64 & 1.99 & 0.71 & 0.00 & 0.20 & 27.83 & 12.39 & 0.00 & 0.41 & 46.94 & 6.08 & 1.65 & 0.79 & 98.99 \\
\hline T9s642 & 2.26 & 1.26 & 0.00 & 0.20 & 27.69 & 12.67 & 0.00 & 0.42 & 45.57 & 5.76 & 1.72 & 0.73 & 98.28 \\
\hline T7s9 & 1.99 & 0.51 & 0.00 & 1.27 & 32.26 & 10.46 & 0.00 & 0.87 & 41.27 & 8.61 & 0.23 & 0.42 & 97.89 \\
\hline T9s68 & 1.69 & 0.89 & 0.00 & 1.50 & 28.75 & 12.43 & 0.14 & 0.82 & 37.01 & 6.60 & 0.35 & 0.36 & 90.54 \\
\hline T11rosa & 1.62 & 0.32 & 0.48 & 0.47 & 23.55 & 14.92 & 1.03 & 0.36 & 44.52 & 5.75 & 2.47 & 0.64 & 96.13 \\
\hline DSM 6210 & 1.57 & 1.26 & 0.43 & 0.49 & 25.61 & 22.73 & 0.11 & 0.28 & 35.86 & 5.92 & 4.00 & 0.63 & 98.89 \\
\hline T 11s & 1.53 & 0.47 & 0.66 & 0.51 & 21.21 & 15.49 & 2.93 & 0.36 & 38.63 & 5.27 & 3.29 & 0.52 & 90.87 \\
\hline
\end{tabular}

Table 6. Fatty acid composition of purple sulfur bacteria (Chromatiaceae) identified by Gas chromatography-Mass spectrometry. $\mathrm{NI}=$ no identified, $\mathrm{X}(\%)=$ average $(\%)$. 
As it is evident, the fatty acid profile of these bacteria not changed among the strains assayed. Similar total (\%) fatty acid results have been reported for this physiological group by Haverkate et al. (1965); Tacks \& Holt (1971); Frederickson et al. (1986); Imhoff (1988); Imhoff \& Thiemann (1991); Macarrón (1998).

Results showed the presence of saturated and unsaturated fatty acids with chains from 12 to C20:1 long; C13:0 as well as aC17:0 were almost present only in phototrophic purple sulfur bacteria with spherical shapes, such as DSM 4197, DSM 5811, DSM 6210, and isolates T1f6, T11s and T11rosa. These results agree with those of Núñez-Cardona et al. (2008), who found the same fatty acids in Amoebobacter sp. (Bk18) and Amoebobacter roseus (DSM 235), which are also spherical. C13:0 fatty acid accounted for less than 1\% (0.42-0.66) and aC17:0 for between 0.11 and $2.93 \%$ of the fatty acids present. Tindall et al. (2010) recommend that all components constituting $1 \%$ or more of the fatty acids must be reported, but according to these results, the identification of $\mathrm{C} 13: 0$ and $a \mathrm{C} 17: 0$ are specific components of two genera (Amoebobacter and Thiocapsa). The importance of reporting minor fatty acids for taxonomic purposes is evident even when the fatty acids are present in percentages below $1 \%$ because minor fatty acids point out the differences among genera and probably among species too.

Imhoff \& Bias Imhoff (1996) expressed that photosynthetic purple sulfur bacteria have equilibrated proportions of $\mathrm{C} 16: 0, \mathrm{C} 16: 1$ and $\mathrm{C} 18: 1$, pointing out $\mathrm{C} 18: 1$ as the most abundant, but not as a major fatty acid. Table 6 shows that, in the conditions described above, C18:1 could account for more than $50 \%$ of the total fatty acids from strains like Chr. salexigens DSM 4395, Tc. halophila DSM 6210 and some Chromatium spp. from marine origin (e.g., T9s64, T9s62, T9s642, T9s69). The order of abundance of fatty acids from purple sulfur bacteria is as follows: C18:0, C16:1, and C16:0. With exception of Chr. tepidum DSM 3771, Chr. salexigens DSM 4395 and Tc. halophila DSM 6210 (extremophilic microorganisms) that present some variations in response to their own specific requirements for growth within the systems they inhabit.

Chr. tepidum DSM 3771 presents more C16:0 than C16:1; hence the fatty acid profile for this strain is: C18:1>C16:1>C16:0. In Tc. halophila DSM 6210, C18:1 is the major fatty acid, and the increase of C16:0 is evident. In Chr. salexigens DSM 4395, C16:0 and C16:1 are almost equals in abundance. In contrast, Chr. purpuratum DSM 1591 showed the lowest quantity of C16:0 (6.59\%), although it conserves the pattern C18:1>C16:1>C16:0, common in phototrophic sulfur bacteria.

With the exception of the data reported by Imhoff and Thiemann (1991) for Chr. purpuratum BN5500, Ec. halophila, and Ec. mobilis, there is no available information on the influence of salinity on fatty acid composition in the Chromatiaceae family. Nevertheless, Tc. halophila DSM 6210, as in Chr. salexigens DSM 4395, grown in salt concentrations of 7 and 10\%, respectively, showed the same behavior as Chr. purpuratum and Ectothiorohospira species; i.e., when there are higher salt concentrations in the culture media, these bacteria produce more saturated fatty acids, especially C16:0 and C18:0, and there is a consequent decrease of C18:1 (Imhoff \& Thiemann, 1991).

Fatty acid C20:1 was detected in almost all strains of the Chromatiaceae family here analyzed; in general, it was not higher than $1 \%(0.3-0.83 \%)$ but in the thermophilic Chr. tepidum, C20:1 accounts for $2.44 \%$ of the total fatty acids. This cellular component was also identified in phospholipids of Thiocapsa spp. (5811 and BF6400) by Macarrón (1998) and in 
intact cells of Chr. purpuratum BN 5500 (Imhoff \& Bias-Imhoff, 1995). It is important to mention that C20:1 was not recorded by Sucharita et al. (2010), using the MIS system, perhaps because MIS is designed to identify fatty acids among 9-20 carbons in length (Sasser, 2001), is not possible to detect the presence of this fatty acid with this system. It is also evident that the results of these authors showed the presence of main fatty acids in four strains of Marichromatium, but only in Mch. indicum, they detailed minor and major fatty acids.

The differences recorded here in the fatty acid compositions of purple sulfur bacteria are in agreement with molecular studies as have been reported by Imhoff \& Caumette (2004). Analysis of $16 \mathrm{~S}$ rDNA revealed genetic differences among marine, halophilic, and the freshwater photosynthetic bacteria. These results led to the taxonomic reclassification and description of new genera of purple photosynthetic sulfur bacteria (Imhoff et al., 1998).

Tree strains of green sulfur bacteria were used to validate the standardized technique for fatty acid analysis of photosynthetic sulfur bacteria and to know the fatty acid profile of another photosynthetic group; results of this analysis are shown in table 7.

\begin{tabular}{|c|c|c|c|}
\hline Fatty acid & DSM 249 & DSM 266 & T11S \\
\hline C12:0 & 1.29 & 0.97 & 1.96 \\
\hline C14:0 & 4.83 & 13.63 & 21.05 \\
\hline 12-me-C14:0 & 0.52 & 0.42 & 0.31 \\
\hline C15:0 & 0.71 & 1.12 & 0.22 \\
\hline C16:1(9) & 30.99 & 36.01 & 26.65 \\
\hline C16:0 & 12.29 & 11.96 & 22.12 \\
\hline aC17:0 & 0.92 & 0.61 & 1.37 \\
\hline 15-me -C16:1 (11) & 0.72 & 0.46 & 0.14 \\
\hline Cyc 17:0 & 3.42 & 1.78 & 0.81 \\
\hline C17:0 & 0.29 & 0.27 & 0.26 \\
\hline C18:1 & 10.33 & 2.97 & 2.9 \\
\hline C18:0 & 0.81 & 0.66 & 0.53 \\
\hline Total (\%) & 67.12 & 70.86 & 78.32 \\
\hline
\end{tabular}

Table 7. Fatty acid detected in three strains of green sulfur bacteria.

As indicated before, for green sulfur bacteria only $250 \mathrm{mg}$ of dried cells was used because of the difficulties to clean the samples. As with purple sulfur bacteria, each green sulfur bacterium was assayed using independent cultures in triplicate. Invariably, after fatty acid extraction and analysis by gas chromatography, the results showed the presence of 12 fatty acids with chains between 12 and 18 carbon atoms in all Chlorobium strains assayed. According to these results, a fatty acid profile for these strains could be C16:1>C16:0 and C14:0. It is also clear that fatty acid composition contains minor components including C12:0, 12-Me-C14:0 (aC15:0), C15:0, C14-Me-C16:0(aC17:0), 15-Me-C16:1, C17:0, C18:1, C18:0, and a cyclic fatty acid (Cyc17:0)

The two hydroxy-acids ( $\mathrm{C} 14: 03 \mathrm{OH}$ and $\mathrm{C} 16: 03: \mathrm{OH})$ were not detected as reported by Knudsen et al. (1982). According to Boon et al. (1997), hydroxyl acids are part of the cellular wall of Gram-negative bacteria and bounded to lipid A and cannot be extracted with soft organic compounds; a special procedure for analysis and extraction is necessary. Nevertheless, in the Marichromatium indicum strain (Sucharita et al., 2010) it was possible to identify hydroxyl fatty acids using the MIS system 
Unbranched fatty acids are characteristic in Gram-positive bacteria; although they have been detected in the Clorobium strains analyzed here. The fatty acids aC15:0 and an aC17:0 were detected previously linked to phospholipids in both Chlorobium limicola and $\mathrm{Cb}$. phaeobacteroides in quantities less than 0.5\% (Macarrón, 1998). Additionally, C15:0 was identified as a fatty acid component of the profile of Chlorobium sp. by Frederickson et al. (1986). 15-Me-C16:1 was the only fatty acid not reported before for green sulfur bacteria.

\section{Conclusions}

Information on fatty acids of photosynthetic purple and green sulfur bacteria is scarce, and the studies of these cellular components are limited to a very low number of collection strains; there is no detailed information about the techniques applied for fatty acid analysis and the genera most studied being Chlorobium, Chromatium and Ectothiorhodospira. With the technique assayed in members of the Chromatiaceae and Chlorobiaceae families it was possible to detect 12 fatty acids both major and minor components. There is clear evidence that extremophilic strains conserve the same fatty acid profile, but there are quantitative differences. The profile of fatty acids in sulfur and green photosynthetic sulfur bacteria is consistent among the strains analyzed, and almost all the fatty acids recorded in these bacteria were previously reported. Fatty acid analysis using standard conditions offers a valuable tool to utilize this information for chemotaxonomic purposes and minor components must be taken into account. Also, it is necessary intensify the study of fatty acids in photosynthetic purple and green sulfur bacteria.

\section{Acknowledgements}

Thanks to the Universitat Autonoma de Barcelona (UAB), Spain, where it was done all the experimental part of the present work with the academic and technical support from Doctors Marina Luquin, Jodi Mas, and Manuel Muñoz. Financial support from the Consejo Nacional de Ciencia y Tecnología (CONACyT, México) and the Universidad Autónoma Metropolitana-Xochimilco is gratefully acknowledged. Also thanks to Dr. Luis Raúl Tovar Galvez (Centro Interdisciplinario de Investigaciones y Estudios sobre Medio Ambiente y Desarrollo-IPN) for his valuable comments to this manuscript.

\section{References}

Abbas, C.A. \& Card, G.L. (1980). The relationships between growth temperature, fatty acid composition and the physical state and fluidity of membrane lipids in Yersinia enterocolitica. Biochimica et Biophysica Acta-Biomembranes, Vol.602, No.3, (November 1980), pp. 469-476, ISSN 0005-2736

Abel, K.; Deschmertzing, H. \& Peterson, J.I. (1963). Classification of Microorganisms by Analysis of Chemical Composition I. Flexibility of Utilizing Gas Chromatography. Journal of Bacteriology, Vol.85, (May 1963), pp. 1039-1044, ISSN 0021-9193

Asselineau, J. \& Trüper H.G. 1982. Lipid composition of six species of phototrophic bacteria genus Ectothiorhodospira. Biochimica et Biophysica Acta-Lipids and Lipid Metabolism, Vol.712, No.1, (July 1982), pp. 111-116. ISSN ISSN 0006-3002

Boom, V.T. \& Cronan Jr., J.E. (1989). Genetics and Regulation of Bacterial Lipid Metabolism. Annual Reviews in Microbiology, Vol.43, (October 1989), pp. 317-343, ISSN 0066-4227. 
Boon, J.J.; de Leeuw, J.W.; Hoek, G.J. \& Vosjan, J.H. (1977). Significance and Taxonomic Value of Iso and Anteiso Monoenoic Fatty Acids and Branched $\beta$-hydroxy acids in Desulfovibrio desulfuricans. Journal of Bacteriology, Vol.129, No.3, (March 1977), pp. 1183-1191, ISSN 0021-9193

Bounsfield, I.J.; Smith, G.L.; Dando, T.R. \& Hobbs, G. (1983). Numerical Analysis of Total Fatty Acids Profiles in the Identification of Corenyform and Some Other Bacteria. Journal of General Microbiology, Vol.129, No.2, (February 1983), pp. 375-394, ISSN 0022-1287

Brondz, I. \& Olsen, I. (1986). Chemotaxonomy of Selected Species of the Actinobacillus Haemophilus-Pasteurella Group by Means of Gas Chromatography-Mass Spectrometry and Bioenzymatic Methods. Journal of Chromatography, Vol.380, (July 1986), pp. 1-17, ISSN 1570-0232

Brown, J.L.; Ross T.; McMeekin, T.A. \& Nichols, P.D. (1997). Acidic Habituation of Escherichia coli and the Potential Role of Cyclopropane Fatty Acids in Low pH Tolerance. International Journal of Food Microbiology, Vol.37, No.2-3, (July 1997), pp. 163-173, ISSN 0168-1605

Bryantseva, I.A.; Tourova, T.P.; Kovaleva, O.L.; Kostrikina, N.A. \& Gorlenko, V.M. (2010). Ectothiorhodospira magna sp. nov., a New Large Alkaliphilic Purple Sulfur Bacterium. Microbiology, Vol.79, No.6, (December 2010), pp. 780-790, ISSN 13500872

Buyer, J.S. (2002). Identification of Bacteria from Single Colonies by Fatty Acid Analysis. Journal of Microbiological Methods, Vol.48, No.2-3, (February, 2002), pp. 259-265. ISSN 0167-7012

Cho, K.Y. \& Salton, M.R.J. (1966). Fatty Acid Composition of Bacterial Membranes and Wall Lipids. Biochimica et Biophysica Acta-Lipids and Metabolism, Vol.116, No.1, (February 1966), pp. 73-79, ISSN 0006-3002.

Cronan J.E.; Reed J.R.; Taylor F.R. \& Jackson, M.B. (1979). Properties and biosynthesis of cyclopropane fatty acids in Escherichia coli. Journal of Bacteriology, Vol.138, No.1, (April 1979) pp. 118-121, ISSN 0021-9193

De Gelder, J. (2008). Raman spectroscopy as a tool for studying bacterial cell compounds. In:http://hdl.handle.net/1854/11263,16.08.2011, 12.08.2011. Available from http://lib.ugent.be/fulltxt/RUG01/001/271/628/RUG01001271628_2010_0001_A C.pdf

Durand-Chastel, H. (1997). Production of Spirulina Rich in GLA and Sulfolipids. International Symposium of Marine Cyanobacteria and Related Organisms. Intitute Ocenographique, Paris. November 24-28, 1997.

Erwin, J. \& Bloch, K. 1964. Biosynthesis of Unsaturated Fatty Acids in Microorganisms. Science, Vol.143, No.3610, (March 1964), pp. 1006-1012, ISSN 0036-8075

Fredrickson, H.L.; Cappenberg, T.E. \& De Leeuw, W.J. (1986). Polar Lipid Ester-Linked Fatty Acid Composition of Lake Vechten Seston: an Ecological Application of Lipid Analysis. FEMS Microbialogy Ecology, Vol.38, No.6, (December 1986), pp. 381-396, ISSN 1574-6941

Grogan, D.W. \& Cronan Jr., J.E. (1997). Cyclopropane Ring Formation in Membrane Lipids of Bacteria. Microbiology and Molecular Biology Reviews. Vol.61, No.4, (December 1997), pp. 429-441, ISSN 1092-2172 
Guschina, I.A. \& Harwood, L.J. (2008). Lipids: Chemical Diversity, In: John Wiley \& Sons Inc. 10.08.2011, Available from http://onlinelibrary.wiley.com /book / 10.1002/ 9780470048672

Haack, S.K.; Garchow, H.; Odelsen, D.A.; Forney, L. \& Klug, M.J. (1994). Accuracy, Reproducibility and Interpretation of Fatty Acid Methyl Ester Profiles of Model Bacterial Communities. Applied and Environmental Microbiology, Vol.50, No.7, (July 1994), pp. 2483-2493, ISNN 0099-2240

Haverkate, F.F.; Teulings, A.G. \& Van Deenen, L.L.M. (1965). Studies on the Phospholipids of Photosynthetic Microorganisms. Proceedings of the Koninklijke Nederlandse Akademie van Wetenschappen Series B, Vol.68, pp.154-159, ISSN: 0920-2250

Imhoff, J.F. (1988). Lipids, Fatty Acids and Quinones in Taxonomy and Phylogeny of Anoxygenic Phototrophic Bacteria, In: Green Photosynthetic Bacteria, J.M Olson, J. Amez, E. Stackebrandt \& H.G. Trüper (Eds.), 223-232. Plenum Press, ISBN 0306429209. New York, USA

Imhoff, J.F. (2008). Systematics of Anoxygenic Phototrophic Bacteria, In: Sulfur Metabolism in Phototrophic Organisms, H. Rüdiger, C. Dahl, D.B. Knaff \& T. Leustek (Eds.), 269287, Springer Verlag, ISBN-10 9048177421, New York, USA.

Imhoff, J.F. \& Bias-Imhoff, U. (1995). Lipids, Quinones and Fatty acids of Anoxygenic Phototrophic Bacteria, In: Anoxygenic Photosynthetic Bacteria, R.E. Blakenship, M.T. Madigan \& C.E. Bauer (Eds.), 179-205, Kluwer Academic Publishers, ISBN 0-79233681-X, The Netherlands

Imhoff, J.F. \& Caumette, P. (2004). Recommended Standards for the Description of New Species of Anoxygenic Phototrophic Bacteria, International Journal of Systematic and Evolutionary Microbiology, Vol.54, No.4, (July 2004), pp. 1415-1421, ISSN 1466-5034

Imhoff, J.F.; Suling, J. \& Petri, R. (1998). Phylogenetic Relationship Among the Chromatiaceae, their Taxonomic Reclassification and Description of the New Genera Allochromatium, Halochromatium, Isochromatium, Marichromatium, Thiococcus, Thiohalocapsa and Thermochromatium. International Journal of Systematic Bacteriology, Vol.48, No.4, (October 1998), pp. 1129-1143, ISSN 0020-7713

Imhoff, J.F. \& Thiel, V. (2010). Phylogeny and Taxonomy of Chlorobiaceae. Photosynthesis Research, Vol.104, No.5-6, (November 2010), pp. 123-136, ISSN 0166-8595.

Imhoff, J.F. \& Thiemann B. (1991). Influence of Salt Concentration and Temperature to the Fatty Acid Composition of Ectothiorhodospira and Other Halophilic Phototrophic Purple Bacteria. Archives of Microbiology, Vol.156, No.5, (October 1991), pp. 370-375, ISSN 0302-8933

Janse, J.D. (1997). Fatty Acid Analysis in the Identification, Taxonomy and Ecology of (Plant Pathogenic) Bacteria. In: Diagnosis and identification of Plant Pathogenes, H.W. Dehne, G. Adam, M. Diekman M, F.J. Mauler-Machnik, P. van Halteren P. (Eds.), 63-70, Kluwer Academic Press Publishers, ISBN 0792347714, The Netherlands.

Jantzen, E. \& Bryan, K. (1985). Whole Cell and Lipopolysaccharide Fatty Acids and Sugars of Gram-Negative Bacteria, In: Chemical Methods in Bacterial Systematics, M. Goodfellow \& D.E. Minnikin (Eds.), 145-171, Academic Press, ISBN-10: 0122896750, London, UK

Kenyon, C.N. (1972). Fatty Acid Composition of Unicellular Strains of Blue-Green Algae. Journal of Bacteriology, Vol.109, No.2, (February 1972), pp. 827-834, ISSN 00 21-9193 
Kenyon, C.N. \& Gray, A.M. (1974). Preliminary Analysis of Lipids and Fatty Acids of Green Bacteria and Chloroflexus aurantiacus. Journal of Bacteriology, Vol.120, No.1, (October 1974), pp. 131-138, ISSN 0021-9193

Knudsen, E.; Jantzen, E.; Bryan, K.; Ormerod, J.G. \& Sirevag, R. (1982). Quantitative and Structural Characteristics of Lipids in Chlorobium and Chloroflexus. Archives of Microbiology, Vol.132, No.2, (August 1982), pp. 149-154, ISSN 0302-8933

Kunistky, C.; Osterhout, G. \& Sasser, M. (2006). Identification of Microorganisms Using Fatty Acids Methyl Ester (FAME) and the MIDI Sherlock Microbial Identification System, 20.08.2011. https://store.pda.org/bookstore/TableOfContents/ERMM_V3_Ch01.pdf

Lakshmi, K.V.N.S.; Sasikala, Ch.; Ramana V.V.; Ramaprasad, E.V.V. \& Ramana, Ch.V. (2011). Rhodovulum phaeolacus sp. nov. a Phototrophic Alphaproteobacterium Isolated From a Brown Pond. Journal of General and Applied Microbiology, Vol.57, No.3, (July 2011), pp.145-151, ISSN 1349-8037

Lechevalier, H. \& Lechevalier, M.P. (1988). Chemotaxonomic Use of Lipids-an Overview, In: Microbial Lipids, C. Ratledge \& S.G. Wilkinson (Eds.), 869-902, Academic Press, ISBN 0125823043, London, UK

Lechevalier, M.P. \& Moss, C.W. (1977). Lipids in Bacterial Taxonomy: a Taxonomist's View. Critical Reviews in Microbiology, Vol.5, No.2, (January 1977), pp. 109-210, ISSN $1040-$ $841 X$

Li, Y.; Wu, S., Wang, L.; Li, Y. \& Shi, F. (2010). Differentiation of Bacteria Using Fatty Acid Profiles from Gas Chromatography-Tandem Mass Spectrometry. Journal of the Science of Food and Agriculture. Vol.90, No.8, (June 2010), pp. 1380-1383, ISSN 10970010

Macarrón G.B. (1998). Utilización de Marcadores Lipídicos en el Estudio de la Biomasa, la Estructura y el Estado Nutricional de las Comunidades de los Tapices Microbianos del Delta del Ebro. Ph. D. Thesis, Universitat Autónoma de Barcelona, España. 250 pp.

Muñoz, M.; Julián, E.; García-Barceló, M.; Ausina V. \& Luquin M. (1997). Easy Differentiation of Mycobacterium mucogenicum, from Other Species of the Mycobacterium fortuitum Complex by Thin Layer and Gas Chromatography of Fatty Esters and Alcohols. Journal of Chromatography B, Vol.689, No.2, (February 1997), pp. 341-347, ISSN 1570-0232

Newton, J.W. \& Newton, N.G.A. (1957). Composition of the Photoactive Subcellular Particles from Chromatium. Archives of Biochemistry and Biophysics, Vol.71, No. 1, (September 1957), pp. 250-265, ISSN: 0003-9861

Nichols, D.S.; Nichols, P.D.; Russel, N.J.; Davies, N.W. \& McMeekin, A.T. (1997). Polyunsaturated Fatty Acids in the Psychrophilic Bacteria Shewanella gelidimarina ACAM 456T: Molecular Species Analysis of Major Phospholipids and Biosynthesis of Eicosapentaenoic Acid. Biochimica et Biohphysica Acta-Lipids and Metabolism, Vol.1347, No.2-3 (August 1997), pp. 164-176, ISSN 0005-2760.

Núñez-Cardona, M.T.; Donato-Rondon, J.Ch.; Mas, J. \& Reynolds, C. (2008). A Phototrophic Sulfur Bacterium from a High Altitude Lake in the Colombian Andes, Journal of Biological Research-Thessaloniki, Vol.9, (June 2008), pp. 17-24, ISSN 1790045X 
Pfennig, N. \& Trüper, H.G. (1981). Isolation of Members of the Families Chromatiaceae and Chlorobiaceae, In: The Prokaryotes, M. Starr, H. Stolp, H.G. Trüper, H.G. Balows, H. Schlegel, (Eds.), 279-289, Springer-Verlag, ISBN 0387-97258-7, New York, USA.

Purcaro, G.; Tranchida, P.Q.; Dugo, P.; La Camera, E.; Bisignano, G.; Conte, L. \& Mondello, L. (2010). Characterization of Bacterial Lipid Profiles by Using Rapid Sample Preparation and Fast Comprehensive Two-Dimensional Gas Chromatography in Combination with Mass Spectrometry. Journal of Separation Science, Vol.33, No.15, (August 2010), pp. 2334- 2340, ISSN 1615-9306

Rabinowitch, H.D.; Sklan, D.; Chance, D.H.; Stevens, R.D. \& Fridowich, I. (1993). Escherichia coli Produces Linoleic Acid During Late Stationary Phase. Journal of Bacteriology, Vol.175, No.17, (September 1993), pp. 5324-5328, ISSN 0021-9193

Rainey, P.B.; Thompson, I.B. \& Palleroni, N.J. (1994). Genome and Fatty Acid Analysis of Pseudomonas stutzeri. International Journal of Systematic Bacteriology, Vol.44, No.1, (January 1994), pp. 54-61, ISSN 0020-77013

Ramana, V.V.; Sasikala, Ch.; Ramaprasad, E.V.V. \& Ramana, Ch.V. (2010). Description of Ecthiorhodospira salini sp. nov. Journal of General and Applied Microbiology, Vol.56, No.4, (August 2010), pp. 313-319, ISSN 1349-8037

Ratledge, C. \& Wilkinson, S.G. (1988). Fatty Acids, Related and Derived Lipids, In: Microbial Lipids, Vol.1, C. Ratledge \& S.G Wilkinson, (Eds.), 23-52, Academic Press, ISBN 0125823045, London UK

Ryu, H.S.; Chung, B.S.; Park, M.; Lee, S.S. \& Jeon, Ch.O. (2008). Rheinheimera soli sp. nov. a $\gamma$-Proteobacterium Isolated from Soil in Korea. International Journal of Systematic and Evolutionary Microbiology, Vol.58, No.10, (October 2008), pp. 2271-2274, ISSN 14665034

Russell, N.J. \& Fukunaga, N. (1990). A Comparison of Thermal Adaptation of Membrane Lipids in Psychrophilic and Themophilic Bacteria. FEMS Microbiology Reviews, Vol.75, No.2-3, (June 1990), pp. 171-182, ISSN 1574-6968

Sasser, M. (2001). Identification of Bacteria by Gas Chromatography of Cellular Fatty Acids, In: MIDI Technical Note \#101. Newark, USA, 08.08.2011. Available from http://www.midi.inc.com

Scheuerbrandt, G. \& Bloch, K. (1962). Unsaturated Fatty Acids in Microorganisms. Journal of Biological Chemistry, Vol.237, No.7, (July 1962), pp. 2064-2068, ISSN 0021-9258

Stanier, R.Y. (1968). Biochemical and Immunological Studies on the Evolution of a Metabolic Pathway in Bacteria. In: Chemotaxonomy and Serotaxonomy, J.G. Hawks, (Ed.), 201225, Academic Press, ISBN-10: 0123333504, London, UK.

Sucharita, K.; Kumar, E.S.; Sasikala, Ch.; Panda, B.B.; Takaichi, S. \& Ramana, Ch.V. (2010). Marichromatium fluminis sp. nov., a Slightly Alkaliphilic, Phototrophic Gammaproteobacterium Isolated from River Sediment. International Journal of Systematic and Evolutionary Microbiology, Vol.60, No.5, (May 2010), pp. 1103-1107, ISSN 14665034 .

Tacks, B.J. \& Holt, S.C. (1971). Thiocapsa floridana: a Cytological, Physical and Chemical Characterization. II. Physical and Chemical Characteristics of Isolated and Reconstituted Chromatophores. Biochimica et Biophysica Acta-Biomembranes, Vol.233, No.2, (April 1971), pp. 278-295, ISSN 0005-2736

Tindall, B.J.; Roselló-Mora, R.; Busse H-J.; Ludwing, W. \& Kampfer, P. (2010). Notes on the Characterization of Prokaryote Strains for Taxonomic Purposes. International 
Journal of Systematic and Evolutionary Microbiology, Vol.60, No.1, (August 2009), pp. 249-266, ISSN 1466-5034

Van Niel, C.B. (1971). Techniques for the Enrichment, Isolation and Maintenance of the Photosynthetic Bacteria. Methods in Enzymology, Photosynthesis Part A (Vol. 23), A. San Pietro (Ed.), 3-28. Academic Press, ISBN: 0121818861/0-12-181886-1, Exeter Dev. UK

Watanabe, K.; Ishikawa, Ch.; Ohtsuka, I.; Kamata, M; Tomita M.; Yazawa, K. \& Muramats, H. (1997), Lipid and Fatty Acids Composition of Novel Docosahexaenoic AcidProducing Marine Bacterium. Lipids, Vol.32, No.9, (September, 1997), pp. 975-978, ISSN: 0024-4201

Yakimov, M.M.; Giuliano, L.; Chernikova, T.N.; Gentile, G.; Abraham, W.-R., Lünsdorf, H.; Timmis, K.N. \& Golyshin, P.N. (2001). Alcalilimnicola halodurans gen. nov., sp. nov., an Alkaliphilic, Moderately Halophilic and Extremely Halotolerant Bacterium, Isolated from Sediments of Soda-Depositing Lake Natron, East Africa Rift Valley. International Journal of Systematic and Evolutionary Microbiology, Vol.5, Part.6, (November 2001), pp. 2133-2143, ISSN 1466-5034

Yano, Y.; Nakayama, A.; Saito, H. \& Ishiharo, K. (1994). Production of Docosahexaenoic Acid by Marine Bacteria Isolated From Deep Sea. Lipids, Vol.29, No.7, (July 1997), pp. 527-528, ISSN 0024-4201

Yawaza, K. (1996). Production of Eicosapentaenoic Acid From Marine Bacteria. Lipids, Vol.31, No.1, (March, 1996), pp. S297-S300, ISSN 0024-4201 


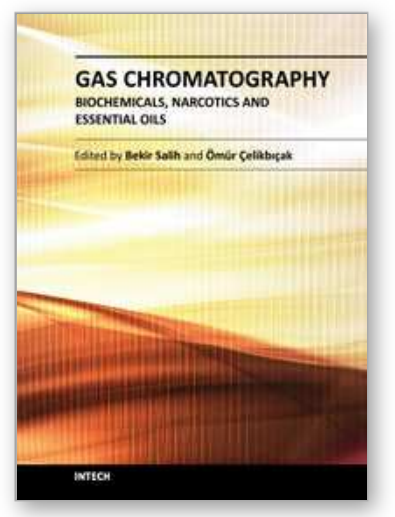

\author{
Gas Chromatography - Biochemicals, Narcotics and Essential Oils \\ Edited by Dr. Bekir Salih
}

ISBN 978-953-51-0295-3

Hard cover, 236 pages

Publisher InTech

Published online 09, March, 2012

Published in print edition March, 2012

Gas Chromatography involves the study of various vaporizable molecules in chemistry and the other related research fields. This analytical method has a number of features and advantages that make it an extremely valuable tool for the identification, quantification and structural elucidation of organic molecules. This book provides detailed gas chromatography information to applications of biochemicals, narcotics and essential oils. The details of the applications were briefly handled by the authors to increase their comprehensibility and feasibility. This guide should be certainly valuable to the novice, as well as to the experienced gas chromatography user who may not have the enough experience about the specific applications covered in this book. We believe this book will prove useful in most laboratories where modern gas chromatography is practiced.

\title{
How to reference
}

In order to correctly reference this scholarly work, feel free to copy and paste the following:

María Teresa Núñez-Cardona (2012). Fatty Acids Analysis of Photosynthetic Sulfur Bacteria by Gas Chromatography, Gas Chromatography - Biochemicals, Narcotics and Essential Oils, Dr. Bekir Salih (Ed.), ISBN: 978-953-51-0295-3, InTech, Available from: http://www.intechopen.com/books/gas-chromatographybiochemicals-narcotics-and-essential-oils/fatty-acids-analysis-of-photosynthetic-sulfur-bacteria-by-gaschromatography

\section{INTECH}

open science | open minds

\section{InTech Europe}

University Campus STeP Ri

Slavka Krautzeka 83/A

51000 Rijeka, Croatia

Phone: +385 (51) 770447

Fax: +385 (51) 686166

www.intechopen.com

\section{InTech China}

Unit 405, Office Block, Hotel Equatorial Shanghai

No.65, Yan An Road (West), Shanghai, 200040, China 中国上海市延安西路65号上海国际贵都大饭店办公楼405单元

Phone: +86-21-62489820

Fax: $+86-21-62489821$ 
(C) 2012 The Author(s). Licensee IntechOpen. This is an open access article distributed under the terms of the Creative Commons Attribution 3.0 License, which permits unrestricted use, distribution, and reproduction in any medium, provided the original work is properly cited. 